\title{
Another Country, Another Time: Notes on Pascal Mercier's Nachtzug nach Lissabon and an idea of Europe
}

\author{
Paulo de Medeiros \\ University of Warwick
}

\begin{abstract}
Pascal Mercier's best-selling novel Night Train to Lisbon and its film adapation are examined as a case study in the relations between North and South and the image of Europe. The novel is significant inasmuch as it counters hegemonic World-Literature tendencies that privilege mostly central, English or French, novels in the European context. It is argued that even though both have significant differences and the novel manages to escape simple clichéd representations of Portugal, both ultimately stage a failure to conceptualize Europe transnationally. Ultimately, the romanticized desire for a would-be more vibrant form of engagement with life and art that would characterize the South does no more than misappropriate its past.
\end{abstract}

Keywords: Pascal Mercier, Night Train to Lisbon, Europe, North-South Relations, World Literature

Resumo: 0 romance de grande sucesso, Comboio nocturne para Lisboa, de Pascal Mercier, assim como o filme nele baseado, são analisados de modo a reflector sobre as relações entre o Norte eo Sul e a imagem da Europa. 0 romance distingue-se ao escaper a tendência hegemónica da Literatura-Global que, em context Europeu, privelegia os romances Ingleses e Franceses. Embora o romance e o filme tenham diferenças significantes entre si, e o romance consiga evitar as representações mais estereotipadas de Portugal, ambos acabam por falhar na representação de uma Europa transnacional. Em última análise o desejo romantizado por um Sul cuja relação com a vida e arte seria mais vivrante mais não faz do que se apropriar indevidamente do seu passado.

Palavras-chave: Pascal Mercier, Comboio nocturno para Lisboa, Europa, Relações Norte-Sul, Literatura-Global 
At the very beginning of one of his most influential books Fredric Jameson provocatively recalls elements of modernism that seemed to have been left behind, cast away and condemned: "In full postmodernity, and until very recently, there had always seemed to be a certain general agreement, a certain unspoken consensus, on those features of the modern that were no longer desirable" (Jameson 2012:13). Jameson's mock astonishment is carried on at some length, so that an unprepared reader might have been led to believe that he too wanted to banish modernism to an unsavory and far-away past. However, Jameson's aim is rather to redefine, and thereby clarify, the related concepts of modern and modernity. As the title of his book indicates, there is only one, singular, modernity, even if it manifests itself differently at different times and in different places. Indeed, to follow on the proposal made by the Warwick Research Collective in Combined and Uneven Development (2015) to read world-literature as the literature of the worldsystem, modernity would always be combined and uneven. The relevance of such a premise has only been foregrounded in the recent events that have led to the 23rd June 2016 referendum in which a scant majority of voters in the UK decided to leave the European Union. This of course has unpredictable consequences for the idea of Europe beyond the merely bureaucratic and administrative nightmares that such a splintering would bring about. Etienne Balibar's assessment of the situation goes directly to the point: "We have passed a threshold in the process of the disaggregation of the European project. This is not because of the British vote, but the referendum did reveal tendencies toward polarisation in the European collective and a both moral and political crisis" (Balibar 2016: 115). None of this happened overnight of course, even if most politicians seem to have been taken by surprise. Indeed, in 2010 Balibar had already declared that the European project faced imminent collapse: "Unless it finds the capacity to start again on radically new bases, Europe is a dead political project" (Balibar 2010). As many observers have rightly noted, the crisis 
in Europe is not just economic but above all political. And part of the political bankruptcy also points to a cultural deficit in which a failure to imagine Europe or a common future for the different European nations and peoples has allowed for a rapid return for the specter of nationalism.

Literature, and perhaps the novel above other genres, could have served as a privileged backdrop in which new forms of community might have been tried out. A novel such as Pascal Mercier's Nachtzug nach Lissabon (2004) with its travel across Europe, and across time, from Portugal's dark period under the Salazar regime to the present, might have been seen as having one such function, bridging differences between North and South without eliding them. As an international best-seller ("over two million copies sold" reads the label on my copy of the English translation, 2008) and even as the basis for a starstudded film by the Danish director Bille August, released in 2013, one could expect that Mercier's novel could even serve as a model for the transnational nature of Europe. Perhaps in a few decades one will be able to determine if that was the case or not. For the moment however, I would argue, what such a novel, and its film adaptation even more so, demonstrate, is both a failure to relate to national specificities and to project a vision towards the future. The difference between the ending of the novel and that of the film is symptomatic of exactly such a failure. Whether Raimund Gregorius, as main protagonist, goes back to Bern to die as the novel leads us to believe is the case, or might remain in Lisbon with a new found zest for life and love as the film suggests, is mostly inconsequential. That is, in relation to the construction of a political project that would aim at a view of Europe as more than just a pile of different, largely incompatible countries. As cultural artifacts, of course there is some, though limited, value to the difference in their endings and I will return to it still.

It can be argued whether the form of the novel itself is specifically European or not and such a debate can be acute amidst competing claims for different views of world literature. Nonetheless, it is not simply a blind Eurocentrism that would lead to a claim for a direct link between the form of the modern novel and the specific socio-political development of Europe at the end of the eighteenth-century. Nor would such a claim imply 
at all that the novel developed equally and simultaneously across Europe. Before proceeding with any consideration of Mercier's novel and its relation to a concept of Europe it is useful to pause for a while and consider the way in which Franco Moretti, in one of his highly influential studies, Atlas of the European Novel, 1800-1900, framed the question of how the modern novel and the concept of Europe are linked:

"Different forms, different Europes. Each genre has its geography - its geometry, almost: but they are all figures without a center. See here how strange novelistic geography is - and doubly strange. Because, first, the novel closes European literature to all external influences: it strengthens, and perhaps even establishes its Europeanness. But then this most European of forms proceeds to deprive most of Europe of all creative autonomy: two cities, London and Paris, rule the entire continent for over a century, publishing half (if not more) of all European novels. It's a ruthless, unprecedented centralization of European literature. Centralization: the center, the well-known fact, but seen for what it really is: not a given, but a process. And a very unlikely process: the exception, not the rule of European literature" (Moretti 1999, 186-87).

Moretti's specific mapping of the European novel and his attention to publishing history provide several important facts that can help ground any discussion of the novel in relation to Europe. At the moment I am specifically concerned with two, related but quite distinct, claims put forth in the passage just cited: one that the novel, "that most European of forms", would be intrinsically linked, at the base even, perhaps, of European identity; the other, that the novel would denote a centralizing movement that would basically turn on the axis London-Paris. Once can argue this and disagree vehemently, either evoking Cervantes or Goethe for instance. However, that is not my intention. Rather, I am concerned with how such claims relate to an understanding of how the European periphery, or semi-periphery in some cases, might relate to this notion of a centralized European identity. On one level I think that it is perfectly clear what Moretti has in mind; yet, on another, it is rather vague as well. It is not as if he would ever forget that beyond the notions of core and periphery, that of the semi-periphery is equally (if not more so) important to understand certain processes in the development of forms and the interaction between literature and politics. That was made clear, should there be any doubts, in the 
discussions surrounding his essay on "Conjectures on World Literature" (Moretti 2000) and the subsequent "More Conjectures" where he explicitly admitted having at one point simplified and left the semi-periphery out of consideration: "By reducing the literary worldsystem to core and periphery, I erased from the picture the transitional area (the semiperiphery) where cultures move in and out of the core" (Moretti, 2003, 77). This is especially relevant for a critique of Mercier's novel inasmuch as it is a novel written by a Swiss author, Peter Bieri (who happens to live and work in Germany, but that is of no consequence for my argument), concerning a Swiss Latin (and Greek) teacher who becomes involved with a Portuguese book - the Portuguese woman he rescues from attempted suicide is only seemingly the trigger for the plot - and travels to Portugal to try and find out more about its author. In Moretti's view, with the European novel spinning out of that double London-Paris axis, Swiss literature (whether written in German or French, to say nothing of Italian or Romansh) will be semi-peripheral at best. As for Portugal, its position in the modern period, is equally one of being semi-peripheral through and through, still playing, or wanting to play, a metropolitan role with regard to its African colonies to the bitter end in 1975, whilst being clearly at the edge of Europe in more senses than one. So that Nachtzug nach Lissabon could be said to be a peripheral novel, written by a semiperipheral author about a semi-peripheral country whose history, even the recent one, is ignored for the largest part by most other Europeans. Except that the novel became a best seller and the film, although it might not have been a success, did have that ambition. Indeed, the film might have been a great disappointment (financially and otherwise) but the prominence of its cast hints at a much grander design. Even if the novel had been mostly unknown, an analysis of its positioning of Europe as a continent to be traversed literally and metaphorically would have been relevant. The novel's central metaphor of the journey, or the quest, as both a discovery of the self as well as a discovery of the other, indeed, as a discovery of the self that is only made possible by the (attempted) discovery of the other, would be important for an understanding of the role played by novels in the formation of a European sense of identity. That the novel became a best-seller and was propelled to wide attention is just icing on the cake of course. 
Before taking on the issue of the North-South relation, or rather its failure, I would like to turn my attention to a vexed issue. One of the striking elements of Moretti's studies has to do with his intensive mapping - literally speaking - of European novels. The use of massive amounts of data and the specific attention to material conditions, including those most directly bearing to the publishing industry are fascinating on their own. However, as is often the case, lists of all kinds tend to reveal as much about themselves as they purportedly do about their very subject. In the ever competing field of the modern novel of course the successive compilations of lists of the classics, or of the best, or of those any cultured person should have read, etc., etc. can be used to elaborate all sorts of conclusions. Even if on a very limited scale I would like to call attention to two such lists and draw some specific conclusions regarding canonicity and the divide between core and periphery. A widespread list of the "100 greatest novels of all time" elaborated by noted critic Robert McCrum and published on 12 October 2002 in the Observer is very elucidating. For instance even though the lists opens with Cervantes' Don Quixote and closes with W. G. Sebalds' Austerlitz (number 1 and number 100 respectively), of its 100 titles just 19 were not originally published in English. This tendency to privilege the canon in English language should not be surprising anymore, although the fact that the list appears to be universal belies the very centrality of English and the (relative) peripheral status of all other literatures or languages. Instead of being corrected in time this pernicious centralization and reduction is only accentuated in the most recent iteration of the list - prepared, readers are told, by McCrum over a period of two years before its publication on 17 August 2015 in the Guardian. The new list abandons the former pretense at cosmopolitanism and clearly presents itself as covering "the 100 best novels written in English". It is perhaps not altogether surprising to see a narrowing of the canon of the "best novels" that clearly favors a national, or at least language-specific, criterium. Such a narrowing merely echoes, and follows in step with, an overall trend across Europe to rekindle the nationalistic key as the crucial element in identity formation. So, one should perhaps rather celebrate the fact that in that revamped list of 2015, about one third of the novels are still not English, even though written in English, with the vast majority of those being American. Because in 2014 the then 
Education Secretary, Mike Gove, announced radical plans to change the secondary school curriculum. Although he was quick to claim that the move was intended to broaden offerings and not exclude anything, most observers quickly noted how American novels were in effect being removed from the lists leading up to the GCSE national examinations. The ideological underpinnings of the plans were perhaps too visible, at least for some commentators. Noted critic Cristopher Bigsby, for instance, deployed some fine irony in his comments published in the Guardian on 25 May 2014:

\begin{abstract}
"It's good to see the union jack of culture fluttering from education central as Michael Gove proposes the omission from the GCSE syllabus of Arthur Miller's The Crucible, John Steinbeck's Of Mice and Men, and Harper Lee's To Kill a Mocking Bird. What possible value, after all, could such texts have? The Crucible concerns a man who stands up against a ruling ideology, rejects expediency and denies the right of those in power to determine his actions. Ah, well, perhaps I see" (Bigsby 2014).
\end{abstract}

Hidden from that debate though, was any reference to European literature. As such, it is noteworthy to look at another such list, "Speaking in Tongues: the greatest European novels chosen by NS friends and contributors" that was published in the New Statesman on 11 June 2016, just before the Referendum on whether or not the United Kingdom should abandon the European Union. There are some striking differences between the list published in the Guardian and this one: whereas both Guardian lists were drawn by one critic and included one hundred novels, the list published in the New Statesman, did not exceed a paltry twenty-three even though it was drawn by twenty-three different authors. Maybe if each one had been allowed to mention two or three novels then one might have approached the hundred of the Guardian lists? But the lingering aftertaste is that coming up with even twenty-three titles already posed some difficulty - even leaving aside the curiosity that Italo Calvino is mentioned twice. Taken like this it is very tempting to say that, from the perspective of English speakers at least, the rest of European literature is peripheral. One could also see it as reinforcing Moretti's finding on the London-Paris axis. Indeed, of all non-English texts mentioned the majority are French as one sees a relatively familiar canon of French modern literature form itself as well: Céine, Alain-Fourrier, Alain 
Robbe-Grillet, Stendahl, Georges Perec. The absences from that canon, that is, the list of equally, if not even more, famous names of French writers like Duras or Yourcenar that somehow fail to be mentioned, is also very significant but I will refrain from dwelling on that for now. It is obvious that the authors asked to provide a name of a European novelist tried to forge an alternative canon as a counterpart to the decidedly nationalist trend, yet produced a list that in can be seen as otherwise conservative as well.

One curious -or rather, predictable - common element to all these lists is that they invariably omit any reference to any works stemming from countries that are not economically central in Europe. As such one does not know how to view the fact that German-language works are almost absent from these lists as well, no more than the fact that of all possibilities from the Italian canon we get two consistent names, Italo Calvino (who, as I said, even makes it twice in just one of the lists) and Carlo Collodi - perhaps Pinocchio is an apt figure in these times of post-truth politics that have swept over Europe? It will not come as a surprise to anyone that not a single work of Portuguese literature will feature in any of those lists, just as the absence of Swiss works should also be seen as the norm. It is this curious, but not much more, that one Swiss author and novel does get mentioned in the New Statesman list: novelist Lionel Shriver selects Peter Stamm's 2009 novel Seven Years (Sieben Jahre), grounding her choice thus:

"It describes a strangely obsessive relationship between a well-educated young man and a lumpen Polish immigrant who is on the face of it charmless, not all that attractive, and kind of stupid. Both the Polish woman and the relationship are lasting in my head; I can conjure the quirky but riveting dynamic almost like a tune or a smell. That's an achievement. I then read Stamm's All Days Are Night, also good, and also weird. I like weird. I like when a book goes somewhere other than where I expect" (Shriver 2016).

On the face of it there would be a significant potential to read Stamm's novel as also engaging - in its fashion - with the question of Europe in a similar way to Mercier's, as it too features an encounter between someone coming from a more central European region, be it Switzerland or Germany, and someone coming from a peripheral region of Europe, be it 
Portugal or Poland. Having both central European characters be male, and both peripheral characters female, adds to the stereotypical, not to say cliché, schematics of both novels but that is not saying much. If anything, Stamm's novel might be usefully analyzed from a perspective of class conflict, something that in Mercier's case is toned down - there is an obvious class difference between two of the male protagonists, the more aristocratic sounding bourgeois Amadeu de Prado and his working class friend, Jorge, but there is never a question of a struggle or even of something like class consciousness surfacing. It is if anything a normalizing feature and definitely less weird, to borrow Shriver's term of praise - or is it endearment - towards Stamm's novels. Nonetheless, I think that it is highly significant that Mercier stages his entire novel basically as a trip, a trip from the stable if boring bourgeois platitudes of Bern into what would be a maelstrom of fierce emotions, political activism, and great literature that seem to characterize the novel's version of Portugal. On the face of it perhaps there is nothing new in this view of the South from a northern perspective, symptomatic of a desire for the other that is usually as twisted and perverse as it is presented as real and the most natural of all possible desires. If Mercier's novel were that simplistic it would hardly merit consideration. The fact that Raimund, the taciturn scholar who leaves his Gymnasium classes behind as he pursues a dream that takes him into Lisbon, does not end up living happily ever after in the sunny South, and makes the inverse journey back to Bern, already points out to the fact that in this novel the NorthSouth clichés, even if present, should not be taken at face-value. Indeed, even the film adaptation, though it panders much more to what it assumes to be a generalized desire for a romantic happy ending and basically hints at the happy life Raimund might after all still have with his beautiful optician, Mariana Eça (Martina Gedeck), leaves it open at the end as the two stand looking at each other in front of the train.

As far as the novel is concerned, two observations impose themselves: one, that desire as enacted by Mercier is rather a complex and multidirectional force that cannot be resumed simply to its most apparently clichéd versions such as the Northern longing for the South, the Winter-Spring romance, even if devoid of its more crass material elements, and the bourgeois romanticization of political engagement. All those become much more 
apparent in the film version, but the novel is in many ways a model of restraint. It does manage to avoid, for the most part at least, just rehashing the banalities of the tourist brochures on Lisbon. The connection between the fascination with Portugal, and with space, so evident in the novel, has been aptly analyzed by Teresa Martins de Oliveira, who makes an important connection between Mercier's own fascination with Portugal, his own sense of displacement and orientalism. She quotes a crucial passage from an interview with Eva Bachmann, originally published in the Tages-Anzeiger on 20 October 2004, in which Bieri mentions his attraction to Portugal's location as end of the world and its history of fascism. Furthermore, and that is what is more relevant for my argument, the character in the novel not only shares that fascination but is a trained orientalist. As Oliveira recognizes and cites, one passage in the novel makes this link very clear and explicit. Raimund talks with one of his earlier pupils, Natalie, and tells her about being at night in the ruins of what had been Amadeu's old school, thinking of his dreams of Persia and experiencing what seems to be a desert wind. As she asks him whether he will learn Persian there, Raimund's tongue-in-cheek answer is more than a simple joke: "Natürlich. Dort ist ja Persien"' (Mercier, 2004: 311). In a novel full of projections, in which a self-admitted goal is the projection of the self into the other as attested by the epigraphs taken from Montaigne's Essays and Fernando Pessoa's Book of Disquiet, the journey from North to South, which as many reviewers noted, actually is an interior journey, the other is above all a projection of one's own desire and the orientalist fantasy, mild as it may be, points to a rather traditional appropriation of Portugal as the exotic other of central Europe, still in Europe, but just barely, a veritable Finisterrae.

The novel does have a certain interest in the difference represented by language and the little snippets of Portuguese it introduces to the text - supposedly as the beginnings of fragments in the book by Amadeu de Prado testify to this interest. Of course they are also just a bit of the exotic liberally sprinkled throughout the novel so as to add it a spice of the foreign. There is no doubt about that but the effect is, shall we say, less crass, than that accomplished by the film where everyone - as several of the reviewers did not fail to notice - speaks English with strangely inflected or affected overtones. Whereas the novel tries to 
preserve in its snippets of Portuguese (the occasional typos are not worst than those one finds in the German text itself) a sense of the polyglossia fundamental to any idea of Europe, the film substitutes for it a blend form of English that, even as it might reflect reality across most of the continent by now, still appears strained and raises more issues than the one it apparently solves, the easing of international communication. More telling still is the fact that the novel is as much about writing as anything else. Afterall, the driving motive that propels Raimund, nicknamed "Mundus" to leave his rather parochial existence in Bern, is not the suicidal young Portuguese woman he saves, but rather the book with its stilted title, Um Ourives das Palavras (A Goldsmith of Words). And this is crucial because it signals the fetishistic nature of Raimund's quest. Not the young woman seduces him but the book, which then becomes fetishized. It is the book, its language and its events, even the people behind it, that Raimund tries to penetrate. Having in mind the orientalist imagining of a lost Persia in Portugal and the colonial origins of the concept of fetish as well as its early development by Marx in relation to the inner mechanisms of capitalism, it is not without irony to see a Swiss Latin teacher fall for the southern magic of a supposed Portuguese author. Except of course that Prado's text, even if evocative, as readers are supposed to notice, of Fernando Pessoa's masterpiece Book of Disquiet, is Mercier's own postmodern appropriation, his own liberation as he commented in an interview with Gunther Blank: “'Mich in Prado hineinzuversetzen war eine unglaubliche Befreiung', resümiert Bieri sein Schreiberlebnis, 'Solche kategorische Urteile, wie sie Prado fällt, würde sich der Privatmensch Peter Bieri nie erlauben'” (“Die zwei Leben des Peter B.”, 2004).

Mercier's novel is a good read and one that raises a number of significant questions, not the least of which is the fundamental philosophical question on the "good life". In a world rendered more and more abject - even staying within the physical boundaries of Europe, or especially staying within those boundaries watching to a great extent powerless as Europe seems to rapidly disintegrate, never having managed to recover from a banking crisis that exposed the other, even more significant, political crisis: one could say that Europe, a certain idea of Europe at least, liberal, social, and sworn to upholding principles of justice and liberty, is at serious risk if not altogether moribund. The title of Etienne Balibar's 
recent book, Europe, crise et fin? (2016) testifies to the current sense of a crisis that has become established. Raimund does try to escape a sense of quiet desperation (as in Pink Floyd's "Time" but also Thoreau's Walden of course: "The mass of men lead lives of quiet desperation"). But ultimately he faces the realization that it is too late to reinvent himself and as such the novel is also a sobering one. The journey then is also a journey into death as the very first epigraph, separated from the other two, and without a German (but English in the translated version) translation, meant to retain, perhaps, the full difference of its original Spanish (that too, selecting a celebrated icon of Castillian culture in a novel seemingly about Portugal, is a further problematic issue). The beginning of the third stanza of Jorge Manrique's Coplas leaves no doubt about the journey being one into death: "Nuestras vidas son los ríos / que van a dar en el mar, / qu'es el morir". As such the novel is also an anti-Bildungsroman as if closing a cycle of modernity in Europe that some would see inaugurated precisely with the rise of the bourgeoisie and with it, of the novel and specifically the novel of education and maturing. Yet, the novel is neither a swan song for Europe nor a morbid paean to a supposedly more vital past. There is little indulgence in nostalgia in the novel - perhaps a consequence or secondary effect of Bieri's disciplinary rigor - in stark contradistinction to the film adaptation that brings out all of Lisbon's scenic qualities in perfect postcard aesthetic and freely indulges in a bit of costume drama frillery, two usually sure draws at the box office.

There is a danger of course, in going to the stockpile of European history and choosing a totalitarian regime to be used as backdrop to one's considerations about the meaning of life. As a reader, and without any recourse to interviews or useless speculations on the author's possible intentions, the text seems to point out to two related fascinations: one, the writing of Pessoa, especially the Book of Disquiet; the other, the notion of resistance to fascism. By combining the two Mercier inherently makes a big claim for a certain ethical quality that would find its expression not only in the sense of duty and responsibility that rule Prado's actions as a gifted student rebelling against the hypocrisies of Catholic society or as a medical doctor - be it his revival of the "Butcher of Lisbon" after he had almost been killed by a group of people in front of his surgery, or his subsequent joining of the resistance 
to atone for that same act. It is as if by doing so Mercier was claiming a heightened purpose to language, which would be able to transcend time and keep on moving us beyond the grave. There is evidently a certain allure to this and great literature can indeed have such an effect. But this is also where Mercier's novel falters. It is in many ways a very successful, complex and sophisticated yet highly readable novel. At face value it would even appear to harken back to a force - passion, commitment, heroism, values - apparently inherent in Modernism (but Prado would have lived in the last two decades of the dictatorship which was toppled in 1974). Yet, any comparison of Prado's texts with Pessoa's (more properly Bernardo Soares') Book of Disquiet should quickly dispel such an illusion. Neither the intensity of Pessoa's texts, nor its obsessive and rigorous character can be matched by Prado's prose even if it attempts to seem poetic. This is not so much a criticism of Mercier as it is a recognition of the power and beauty of Pessoa's texts, of their ability to truly transcend time. Alain Badiou's injunction for us to become contemporaries of Pessoa, indeed for us to assume that as a philosophical task is still as urgent today as when he first proffered it in his Handbook of Inaesthetics, when, after passing in review a number of philosophers from Heidegger and Deleuze to José Gil he states, not without some provocation: "We must therefore conclude that philosophy is not - at least not yet - under the condition of Pessoa. Its thought is not yet worthy of Pessoa (Badiou, 2005 [1998], 36).

If Mercier's novel fetishizes the book - and perhaps that is the very aim of Amadeu de Prado's faint replica of the Book of Disquiet, to offer itself always as a substitute for the object of desire - August's film, in its attempt to stay as close as possible to Mercier's novel actually fails to reproduce it. Had August sought a cinematic equivalent for the rhetorically charged imagery of Prado's texts, it might have attempted to remain at the level of the novel and capitalized on the plot's desire for engagement with the past, with tragic love, with fascism, with death. Instead, by relying on having Jeremy Irons, in his role as Raimund, read us passages from Prado's book merely renders those passages even more stilted. The film's reviews generally tended to acknowledge that having a good story and a star cast do not necessarily add up to a great film. Indeed, the headline of the review in Die Welt, by Peter Zander, can be seen as representative when it announces the train as "rattling" into kitsch: 
"Der Nachtzug nach Lissabon rattert in den Kitsch" (2013). However, it is not just at the level of aesthetic judgment that the film falls short. Beyond any questions of the form specific to film adaptation, or concerning the techniques of transmediation, as important as they are, what is troubling is the utter romanticization of the struggle against fascism. It is not simply that there are no nuances to the films' good and evil struggle, but that either inadvertently or out of some misguided artistic notion ("literature is a more intellectual medium, whereas film is an emotional medium", "Five Questions", 2013) the film sets up the struggle it purports to evoke and represent as almost a form of adolescent play. As if the past were simply yet another curiosity and not a force still shaping the lives of many. The film, even though it might seem to give some attention to remembering, actually contributes more towards a flattening and ultimate erasure of that very past it would pretend to evoke. Not intentionally, not even perhaps with any awareness of what it does and fails to do. This is how August expressed his interest in Portugal's dictatorship and what he wanted to portray in the film:

\footnotetext{
"What I also found interesting was that the history of Portugal and especially that period of dictatorship is something that very few people know anything about, because they know a lot about Spain or Franco. And also because the fascists in Spain were much more expressive. Salazar, the dictator, he was a very elegant man, he was a lawyer. The fascists in Portugal did not look like a fascist regime but they were very, very cruel. So the suppression was the same, and that was something we were also trying to capture in the film" ("Five Questions" 2013).
}

Mercier's novel presents us with a Europe split between North and South and with a longing for what the South comes to represent, passion, youth, tragedy, life, versus the solid, solitary routine of a soulless existence on its rapid way towards extinction. It also presents us with a, even if relatively mild, view of Europe as indeed characterized by untold suffering without simply conflating one form of totalitarianism with another. The novel's sober ending is also significant inasmuch as it refuses a facile conflating of individual cultures at the same time that it foregoes any escapist romantic resolution to Raimund's crisis. Even though in the novel Raimund goes back to Bern in the end, the image the novel holds of 
Europe is more hopeful than that left behind by the film. Precisely in the recognition of the differences inherent to the multiple European nations and their specific histories the novel opens up a path for a transnational view of Europe. Here, one could think of Habermas' analysis in his essay on "Why Europe Needs a Constitution":

\begin{abstract}
"What forms the common core of a European identity is the character of the painful learning process it has gone through, as much as its results. It is the lasting memory of nationalist excess and moral abyss that lends to our present commitments the quality of a peculiar achievement. This historical background should ease the transition to a post-national democracy based on the mutual recognition of the differences between strong and proud national cultures" (Habermas 2001,21).
\end{abstract}

Of course that was fifteen years ago and the new political realities that show an ever growing rise in nationalistic and xenophobic behaviors led on by a spreading host of new demagogues, almost makes Habermas sound like a hopelessly utopian thinker. Which he is not. Unwittingly, August's film, in spite of being itself a European, transnational production, ends up by undermining the sense of a Europe commonly united by a shared history of suffering and a hope towards a different future. By deploying a whole string of tired clichés about Portugal and leveling its history of almost fifty years of fascism, the film comes close to simply denying its difference, without in any way suggesting that it would be a common European experience. Perhaps the only "European" aspect of the film is the erasure of linguistic difference and its substitution by a variety of accents in English. If the novel fetishizes the power of language and the idea of the book, the film in its turn, with its "readings" from the book, ends up by fetishizing the fetish itself. If, as Moretti would have it, the Bildungsroman is the form of modernity (Moretti 2000 [1987], 5), then Mercier's novel as an anti-Bildungsroman would be the form of a post-modernity intent on recuperating as much of the aura (still there) of modernity for present consumption. The film does no more than render that form into its own shell as it empties out the various concepts it deals with, from modernity to resistance, and offers us in their stead a mild and vaguely pleasurable form of entertainment, with just a pinch of nostalgia and a love for ruins, very much in the mode of an updated version of the 1981 serial TV series Brideshead Revisited, transplanted 
into Portugal. Viewers of The Matrix, the cult film about a post-apocalyptic society in which the world lies in ruins but this is disguised by a form of virtual reality (and even nonviewers as the scene has entered into popular culture) will remember how the character Morpheus (Laurence Fishburne) gives the hero, Neo (Keanu Reeves) a choice between taking the red or the blue pill. If Neo chooses the blue he will go to sleep and upon waking up he can believe whatever he wants; if he takes the red pill he will be taken by Morpheus "down the rabbit hole" and experience reality for himself. I realize that it might seem as if, from the beginning, my argument has been to oppose Mercier's novel to August's film as if in one way or another, one would be the red pill and the other the blue. But that is not my point at all. Both the novel and the film fail to advance any possibility for a conceptualization of Europe that would truly advance along the lines of what Habermas and many with him - dared envision for the future. The differences between the novel and the film - and there are many I did not even bring out - are important but not in terms of their possible relevance for an idea of Europe. The ending, for instance, shows a stark contrast between a return to Bern and, it seems, a journey to death in the novel, and the romantic imagination of a future together for Raimund and his newly found "Portuguese" beauty in the film. But both endings are merely consistent with their respective narratives. What separates them is a greater sense of the place of death in life on the part of Mercier, and a corresponding desire to have a happy ending no matter what on the part of August. Neither ending really comes as a surprise and neither one does anything to show any advancement towards a concept of Europe that would be functional and not "dead" from the start, or simply a form of wish fulfillment. As such, there is no blue pill and red pill to choose from as both pills are ultimately the blue pill and the idea of a red pill, rumor has it, is yet another form of illusion, another country, another time: "Dort ist ja Persien". 


\section{Works Cited}

Badiou, Alain (2005) [1998], Handbook of Inaesthetics, Transl. Alberto Toscano, Stanford: Stanford University Press.

Balibar, Etienne (2010), “Europe: Final Crisis? Some Theses”, Theory \& Event 13.2: n.p.

Balibar, Etienne (2016), "Brexit, the Anti-Grexit", in The Brexit Crisis: A Verso Report, London, Verso: 110-116.

Balibar, Etienne (2016), Europe, crise et fin?, Lormont, Le bord de l'eau.

Bille, August (dir.), (2013), Night Train to Lisbon, Bulldog Studios, DVD.

Brideshead Revisited (1981), ITV.

"Die zwei Leben des Peter B." (2004), Interview of Gunther Blank with Pascal Mercier, Welt am Sonntag, 31 October, http://www.welt.de/print-wams/article117382/Die-zwei-Lebendes-Peter-B.html.

Faulkner, William, (2015) [1950], Requiem for a Nun, London, Vintage, 85.

"Five Questions with Night Train to Lisbon Director Bille August" (2013), Ariston Anderson, Film Maker, 29 March, http://filmmakermagazine.com/67616-five-questions-with-nighttrain-to-lisbon-director-bille-august/\#.V6UsWmVQmLU.

Habermas, Jürgen (2001), “Why Europe Needs a Constitution”, New Left Review 11, 5-26.

Jameson, Fredric (2012), A Singular Modernity, London, Verso.

Mercier, Pascal (2004), Nachtzug nach Lissabon, München, Wien, Carl Hanser Verlag.

Mercier, Pascal (2008), Night Train to Lisbon, Transl. Barbara Harshaw, London, Atlantic Books.

Moretti, Franco (1999), Atlas of the European Novel, 1800-1900, London, Verso.

Moretti, Franco (2000) [1987], The Way of the World: The Bildungsroman in European Culture, New edition, Transl. Albert Sbragia, London, Verso. 
Moretti, Franco (2000), “Conjectures on World Literature”, New Left Review 1: 54-68.

Moretti, Franco (2003), “More Conjectures”, New Left Review 20:73-81.

Oliveira, Teresa Martins de (2009), "Raumgestaltungen und ihre Bedeutungen in Pascal Merciers Nachtzug nach Lissabon" in Jenseits von Frisch und Dürrenmatt. Raumgestaltung in der gegenwärtigen Deutschschweitzer Literatur, Würzburg, Königshausen \& Neumann, 2009, 63-72.

Pessoa, Fernando (2001), The Book of Disquiet, transl. Richard Zenith, Lonson, Penguin.

Shriver, Lionel (2016), "Seven Years" in "Speaking in Tongues: the greatest European novels, chosen by NS friends and contributors". http://www.newstatesman.com/culture/ books/2016/06/speaking-tongues-greatest-european-novels-chosen-ns-friends-andcontributors.

The Matrix (1999), dir. The Wachowski Brothers, Warner Bros.

Thoreau, Henry (2004) [1854], Walden: A Fully Annotated Edition, ed. Jeffrey S. Cramer, New Haven, Yale University Press.

Warwick Research Collective (2015), Combined and Uneven Development: Towards a New Theory of World-Literature, Liverpool: University of Liverpool Press.

Zander, Peter (2013), “Der Nachtzug nach Lissabon rattert in den Kitsch”, Die Welt, 7 March, http://www.welt.de/kultur/article114241720/Der-Nachtzug-nach-Lissabon-rattert-inden-Kitsch.html. 
Paulo de Medeiros is Professor of Modern and Contemporary World Literatures, and teaches on the English and Comparative Literary Studies program at Warwick University. In 2011-2012 he was Keeley Fellow at Wadham College, Oxford and in 2013 and 2014 President of the American Portuguese Studies Association. In 2015 he published O Silêncio das Sereias: Ensaio sobre o Livro do Desassossego. Current projects include a study on Postimperial Europe. 